\title{
Keikutsertaan Pria dalam Program Keluarga Berencana di Indonesia
}

\author{
Men Participation in Family Planning in Indonesia
}

\author{
Musafaah
}

Program Studi Kesehatan Masyarakat Fakultas Kedokteran Universitas Lambung Mangkurat Kalimantan Selatan

\begin{abstract}
Abstrak
Pria telah mengikuti program keluarga berencana (KB) sejak dahulu. Metode pantang berkala dan kondom telah dikenal berabad-abad lalu, tetapi sejak ditemukan kontrasepsi wanita, program KB pada pria seakan diabaikan. Keikutsertaan pria dalam ber-KB masih sangat rendah jika dibandingkan dengan Bangladesh, Pakistan, dan Nepal. Penelitian ini bertujuan untuk menganalisis keikutsertaan pria dalam ber-KB meliputi keterpaparan media massa dan kontak informasi KB melalui media massa. Penelitian ini menggunakan data Survei Demografi dan Kesehatan Indonesia (SDKI) tahun 2007 dengan pendekatan cross sectional terhadap 6.013 pria menikah usia $15-54$ tahun. Teknik pengambilan sampel yang digunakan adalah two stage sampling. Analisis data menggunakan chi square dan regresi logistik. Penelitian menunjukkan bahwa pria yang terpapar dengan media massa memiliki kecenderungan 2,12 kali lebih besar untuk ber-KB daripada pria yang kurang terpapar dengan media massa. Selain itu, penelitian juga menunjukkan bahwa pria yang kontak informasi KB melalui media massa memiliki kecenderungan 2,21 kali lebih besar untuk ber-KB daripada pria yang tidak kontak informasi KB melalui media massa. Penelitian ini menunjukkan pria memiliki kecenderungan terbesar untuk ber-KB apabila pria terpapar media massa dan mendapatkan informasi $\mathrm{KB}$ melalui media massa dengan $\mathrm{OR}$ yang terbesar $=2,77$.

Kata kunci: keikutsertaan pria, keluarga berencana, media massa
\end{abstract}

\begin{abstract}
Men already used contraception with withdrawal and condom which had known centuries ago. Since contraception for women was found, men family planning program was likely ignored. The involving of men in family planning in Indonesia is still lower than Bangladesh, Pakistan, and Nepal. The objective of this study is to analyze the credencial factor of men participation in family planning through mass media exposure and contact information. This study used Indonesia Demografic and Health Survey (IDHS) 2007 data used cross-sectional study and 6.013 married men aged 15 - 54 years
\end{abstract}

old as participants. Sampling method used is two stage sampling. Data was analyzed by chi square and logistic regression. The research showed that men who were exposed mass media 2,12 times more involved in family planning than men who were not exposed mass media and men who were contact information in family planning through mass media 2,21 times more participating in family planning than men who were not. The result showed that men have the highest possibility to participate in family planning if exposed by mass media and contacted to family planning information through mass media with biggest $\mathrm{OR}=2,77$.

Keywords: The involvement of men, family planning, mass media

\section{Pendahuluan}

Sensus penduduk tahun 2010 menunjukkan jumlah penduduk Indonesia berjumlah 237,6 juta. Jumlah ini sangat besar sehingga diperlukan pengendalian jumlah penduduk. ${ }^{1}$ Selain itu, angka kematian ibu (AKI) dan angka kematian bayi (AKB) yaitu 228 kematian ibu per 100.000 kelahiran hidup dan 34 angka kematian bayi per 1.000 kelahiran masih tinggi. ${ }^{2}$ Angka ini tertinggi jika dibandingkan dengan negara ASEAN lainnya, seperti Thailand, Malaysia, Vietnam, Brunei, dan Singapura. ${ }^{3}$ Kebijakan Kementerian Kesehatan dalam upaya mempercepat penurunan AKI pada dasarnya mengacu kepada intervensi strategis "Empat Pilar Safe Motherhood", yaitu 1) keluarga berencana (KB), 2) pelayanan antenatal, 3) persalinan yang aman, dan 4) pelayanan obstetri esensial. ${ }^{4}$ Keluarga Berencana (KB) adalah salah satu metode untuk mengendalikan jumlah penduduk. ${ }^{5}$

Alamat Korespondensi: Musafaah, Prodi Kesehatan Masyarakat FK

Universitas Lambung Mangkurat Kalimantan Selatan, Jl. A. Yani Km 36,5

Banjarbaru 70714, Hp.085332142777, e-mail: fahmi0104@yahoo.co.id 
Selama berabad-abad, pria telah melakukan kontrol fertilitas yang paling dasar melalui penggunaan metode kontrasepsi untuk mengatur jarak kelahiran secara tradisional, seperti pantang berkala dan pantang berhubungan seksual setelah kelahiran. Kondom yang telah digunakan sejak kurang lebih 400 tahun yang lalu dilanjutkan sebagai kontrol fertilitas pria yang dominan. ${ }^{6}$

Di negara berkembang, hampir semua pelayanan $\mathrm{KB}$ ditujukan untuk wanita, sehingga perhatian pada pria kecil, serta masih terdapatnya pertentangan dengan keyakinan agama. ${ }^{7}$ Sebagian besar program KB memberikan perhatian yang sedikit pada pemahaman peranan pria dalam penggunaan kontrasepsi yang efektif dan konsisten. Metode yang membutuhkan keterlibatan pria, seperti kondom, pantang berkala, senggama terputus, dan vasektomi jarang digunakan. ${ }^{8}$ Sampai sekarang, program KB hanya fokus pada sikap dan perilaku wanita. Wanita dijadikan target informasi, pendidikan, dan komunikasi dalam peningkatan pengetahuan dan pemakaian kontrasepsi. Konsekuensinya, peranan pria yang sangat besar dalam memengaruhi proses pengambilan keputusan diabaikan. ${ }^{9}$ Sebagian program KB menawarkan dan mempromosikan metode kontrasepsi seperti pil dan suntik yang digunakan wanita. Padahal, keefektifan dan keberlanjutan pemakaiannya sering tidak berhasil disebabkan ketidaksetujuan suami. ${ }^{10}$ Keikutsertaan pria menikah di Indonesia masih rendah yaitu 5,5\%. ${ }^{9}$ Angka tersebut sangat rendah bila dibandingkan dengan negara lain seperti Bangladesh 19,1\% Pakistan 10,9\%, dan Nepal $18 \% .11,12$

Partisipasi pria menjadi penting dalam KB dan kesehatan reproduksi karena: pertama, pria adalah partner dalam reproduksi dan seksual, sehingga sangat beralasan apabila pria dan wanita berbagi tanggung jawab dan peran secara seimbang untuk mencapai kepuasan kehidupan seksual dan berbagi beban untuk mencegah penyakit serta komplikasi KB dan kesehatan reproduksi. Kedua, pria bertanggung jawab secara sosial dan ekonomi termasuk untuk anak-anaknya, sehingga keterlibatan pria dalam keputusan reproduksi akan membentuk ikatan yang lebih kuat dengan istri dan keturunannya. Ketiga, pria secara nyata terlibat dalam fertilitas dan memiliki peranan yang penting dalam memutuskan kontrasepsi yang akan dipakainya atau digunakan istrinya, serta dukungan kepada pasangan terhadap kehidupan reproduksi seperti pada saat, sedang, dan setelah melahirkan serta selama menyusui. ${ }^{13}$ Bentuk partisipasi pria dalam KB dapat dilakukan secara langsung dan tidak langsung. Partisipasi pria secara langsung adalah menggunakan salah satu cara atau metode pencegahan kehamilan, seperti kondom, vasektomi (kontap pria), serta KB alamiah yang melibatkan pria meliputi metode sanggama terputus dan metode pantang berkala. ${ }^{14}$

\section{Metode}

Penelitian menggunakan desain studi cross sectional dengan metode sampling dua tahap (two stages sampling). Penelitian ini menggunakan sumber data sekunder Survei Demografi dan Kesehatan Indonesia (SDKI) Tahun 2007. Penarikan sampel dilakukan oleh Badan Pusat Statistik (BPS) dengan menggunakan metode probability proportional to size. Pada tahap kedua, dari setiap blok sensus yang terpilih, dipilih sampel 25 rumah tangga secara sistematis. Pengumpulan data pada rumah tangga terpilih oleh SDKI 2007 dilakukan melalui wawancara langsung (tatap muka) antara pewawancara dengan responden. Pengumpulan data dengan menggunakan Kuesioner Modul Pria Kawin (PK) SDKI 2007 ditujukan kepada pria menikah yang telah berusia $15-54$ tahun.

\section{Hasil}

Hanya sebagian kecil pria $(6,2 \%)$ yang ikut program keluarga berencana, dan sebagian besar pria yang ikut ber-KB menggunakan kondom $(50,8 \%)$ dan senggama terputus $(27,0 \%)$. Sebagian besar responden terpapar KB melalui media massa $(62,3 \%)$ dan kurang dari setengah responden mempunyai kontak informasi $\mathrm{KB}$ dengan media massa (Tabel 1).

Proporsi pria yang terpapar dengan media massa dan ikut ber-KB $(7,7 \%)$ lebih besar daripada yang kurang terpapar dengan media massa dan ikut ber-KB $(3,8 \%)$. Hasil uji chi square menghasilkan odds ratio $(\mathrm{OR})=2,12$ dan nilai $\mathrm{p}=0,001$, artinya pria yang terpapar media massa mempunyai kecenderungan 2,12 kali lebih besar untuk ber-KB daripada pria yang kurang terpapar dengan media massa. Persentase pria yang kontak informasi KB melalui media massa dan ikut ber-KB $(8,8 \%)$ lebih besar daripada persentase yang tidak kontak informasi $\mathrm{KB}$ melalui media massa dan ikut ber-KB $(4,2 \%)$. Hasil uji chi square mendapatkan nilai $\mathrm{OR}=2,21$ dan nilai $\mathrm{p}=$ 0,001 , pria yang mendapat kontak informasi KB melalui media massa mempunyai kecenderungan 2,21 kali lebih

Tabel 1. Distribusi Responden Berdasarkan Status Peserta KB, Keterpaparan Media, dan Kontak Media Massa $(n=6.013)$

\begin{tabular}{lll}
\hline Variabel & Persentase (\%) & 95\% CI \\
\hline Keikutsertaan KB & 6,2 & $5,3-7,3$ \\
Sterilisasi pria & 1,3 & \\
Kondom & 50,8 & \\
Pantang berkala & 18,4 & \\
Sanggama terputus & 27,0 & \\
Metode lain & 2,6 & $59,9-64,7$ \\
Keterpaparan media massa & & $35,3-40,1$ \\
Terpapar & 62,3 & \\
Kurang terpapar & 37,7 & $41,1-45,6$ \\
Kontak media massa & & $54,4-58,9$ \\
$\quad$ Ya & 43,4 & \\
Tidak & 56,6 & \\
\hline
\end{tabular}


Tabel 2. Analisis Bivariat Keikutsertaan Pria dalam Keluarga Berencana $(n=6.013$ )

\begin{tabular}{lllll}
\hline Variabel Independen & Kategori & OR & 95\% CI & Nilai p \\
\hline Keterpaparan media massa & $\begin{array}{l}\text { Terpapar } \\
\text { Kurang terpapar } \\
\text { Kontak informasi KB media massa }\end{array}$ & 2,12 & $1,43-3,14$ & 0,001 \\
& $\begin{array}{l}\text { Ya } \\
\text { Tidak }\end{array}$ & 2,21 & $1,58-3,08$ & 0,001 \\
\hline
\end{tabular}

Tabel 3. Model Akhir Analisis Regresi Logistik Ganda Faktor yang Mempengaruhi Keikutsertaan Pria dalam Keluarga Berencana

\begin{tabular}{lllll}
\hline Variabel Independen & $\boldsymbol{\beta}$ & OR & $\mathbf{9 5 \%} \mathbf{C I}$ & Nilai p \\
\hline Konstanta & $-3,24$ & 0,039 & $0,026-0,058$ & 0,000 \\
Keterpaparan media massa & 0,235 & 1,26 & $0,78-2,06$ & 0,347 \\
Kontak informasi KB melalui media massa & 0,045 & 1,05 & $0,58-1,90$ & 0,882 \\
Keterpaparan media massa*kontak & 0,784 & 2,19 & $1,13-4,25$ & 0,021 \\
informasi KB melalui media massa & & & & \\
\hline
\end{tabular}

besar untuk ber-KB daripada pria yang tidak mendapat kontak informasi KB melalui media massa (Tabel 2).

Berdasarkan analisis bivariat, terpilih dua variabel meliputi keterpaparan media massa dan kontak informasi KB melalui media massa dengan nilai $\mathrm{p} \leq 0,25$ untuk dimasukkan dalam model analisis regresi logistik ganda secara bersama. Hasil analisis regresi logistik ganda menunjukkan odds ratio keterpaparan media massa dan kontak informasi KB melalui media massa setelah saling dikontrol dan interaksi antara keterpaparan media massa dan kontak informasi KB melalui media massa menjadi 1,26 dan 1,05. Pria yang terpapar dengan media massa berpeluang 1,26 kali lebih besar untuk ber-KB daripada pria yang kurang terpapar dengan media massa. Pria yang kontak informasi KB melalui media massa memiliki kecenderungan 1,05 kali lebih besar untuk ber$\mathrm{KB}$ daripada pria yang tidak kontak informasi KB melalui media massa. OR untuk pria yang terpapar media massa dan tidak kontak informasi KB melalui media massa adalah 2,19, sedangkan OR untuk pria yang terpapar media massa dan kontak informasi $\mathrm{KB}$ melalui media mas$\mathrm{sa}=\exp (0,235+0,784)=\exp (1,019)=2,77$. Faktor yang dominan dalam keikutsertaan pria dalam ber-KB adalah interaksi antara keterpaparan media massa dan kontak informasi melalui media massa yaitu pria yang memiliki kecenderungan terbesar untuk ber-KB apabila terpapar media massa dan mendapatkan informasi KB melalui media massa dengan $\mathrm{OR}=2,77$ (Tabel 3).

\section{Pembahasan}

Sebagian besar pria di Indonesia tidak ikut KB. Fakta ini menunjukkan bahwa program KB di Indonesia belum berhasil mengajak pria ber-KB. Hal ini disebabkan kemungkinan program KB di Indonesia masih terfokus pa- da wanita. Sebagian besar pria di Indonesia yang ber-KB menggunakan alat kontrasepsi kondom yang menunjukkan bahwa kondom adalah alat kontrasepsi yang paling dikenal dan diminati di kalangan pria. Kondom yang kemudian dilanjutkan sebagai alat pengendali fertilitas pria yang dominan memang telah digunakan sejak sekitar 400 tahun lalu. ${ }^{6}$ Pilihan kondom sebagai alat kontrasepsi juga mencerminkan keterbatasan pria dalam memilih alat kontrasepsi.

Responden yang terpapar media massa lebih banyak yang ikut ber-KB daripada responden yang tidak terpapar media massa. Selain itu, responden yang kontak informasi KB melalui media massa juga lebih banyak yang ikut ber-KB daripada responden yang tidak mendapat kontak informasi KB melalui media massa. Pertanyaan umum tentang pengaruh media massa terhadap perilaku seseorang banyak diperdebatkan, termasuk efek televisi terhadap kekerasan, pendidikan anak, dan produk pilihan konsumen. Bukti keefektifan media tersebut beragam, tetapi komunikasi media massa dapat menginformasikan dan memotivasi seseorang dalam memilih metode $\mathrm{KB}$, sehingga bermanfaat mengatur fertilitas sebagai tujuan reproduksi mereka. ${ }^{15}$

Berbagai penelitian secara konsisten menemukan bahwa keterpaparan dengan media massa berdampak positif terhadap keikutsertaan pria dalam program keluarga berencana. Keterpaparan media berdampak kuat pada perilaku dan sikap reproduksi, termasuk keikutsertaan pria dalam ber-KB. ${ }^{16}$ Terdapat hubungan yang signifikan antara akses media massa dengan penggunaan metode kontrasepsi pada pria. ${ }^{17}$ Keterpaparan dengan media berpengaruh signifikan terhadap penggunaan kontrasepsi pada pria. ${ }^{18}$ Keterpaparan media audiovisual penting bagi pria dalam menentukan perilaku yang berhubungan 
dengan kontrasepsi. ${ }^{19}$

Penelitian ini menemukan bahwa pria yang mengalami kontak dengan informasi $\mathrm{KB}$ melalui media massa lebih mempunyai kecenderungan untuk ber-KB daripada pria yang tidak mendapat kontak informasi KB melalui media massa. Promosi KB di media massa ternyata memberi dampak bagi keikutsertaan pria dalam ber-KB. Pesan-pesan audio seperti pesan KB atau pesan visual melalui koran mempunyai peran penting dalam meningkatkan kesadaran akan kontrasepsi. Kontak pesan atau informasi KB berdampak kuat pada perilaku dan sikap reproduksi, termasuk keikutsertaan pria dalam ber-KB. Kontak informasi KB melalui TV, radio, dan koran penting dalam membentuk sikap dan perilaku reproduksi seseorang. ${ }^{16,20}$

\section{Kesimpulan}

Kesertaaan pria di Indonesia dalam program KB secara nasional masih tergolong rendah. Pria yang terpapar media massa mempunyai kecenderungan yang lebih besar untuk ber-KB daripada pria yang tidak terpapar dengan media massa. Selain itu, pria yang mendapat kontak KB melalui media massa lebih mempunyai kecenderungan untuk ber-KB daripada pria yang tidak mendapat kontak KB melalui media massa.

\section{Saran}

Media massa memegang peranan penting dalam mendorong pria untuk ber-KB, sehingga pihak yang berkepentingan diharapkan terus meningkatkan promosi $\mathrm{KB}$ melalui media massa seperti TV, radio, dan koran/majalah.

\section{Daftar Pustaka}

1. Badan Pusat Statistik. Penduduk Indonesia menurut provinsi 1971, 1980, 1990, 1995, 2000 dan 2010 [cited 2011 Apr 10]. Available from: www.bps.go.id.

2. Badan Pusat Statistik dan Macro International. Indonesia demographic and health survey 2007. Calverton, Maryland, USA: Badan Pusat Statistik dan Macro International dan Macro International; 2008.

3. Badan Kependudukan dan Keluarga Berencana Nasional. Draft grand strategi peningkatan partisipasi pria sebagai peserta KB. Jakarta: Badan Kependudukan dan Keluarga Berencana Nasional; 2006.

4. Saifuddin. Buku acuan nasional pelayanan kesehatan maternal dan neonatal. Jakarta: Jaringan Nasional Pelatihan Klinik Kesehatan Reproduksi-Perkumpulan Obstetri dan Ginekologi Indonesia; 2001.

5. Dwijayanti R. Analisis respon masyarakat desa terhadap program KB dalam rangka peningkatan kualitas sumber daya manusia di Desa Cihideung Udik Kabupaten Bogor. 2006 [cited 2011 Mar12]. Available from : http://dikti.go.id/pkm/pkmi-award- 2006/pdf/pkmi06-016.pdf.
6. United Nations Fund for Population Activities. Techinal support: male involvement in reproductive health, including family planning and sexual health. Number 28. New York; 1995.

7. Olawepo RA, Okedare EA. Men's attitudes towards family planning in a traditional urban centre: an example from Ilorin, Nigeria. Jurnal Social Science. 2006; 13 (2): 83-90.

8. Ezeh AC, Serousi M, Raggers H. Men's fertility, contraceptive use and reproductive preference. Demographic and Health Survey, Comparative Studies. Number 18. Maryland: Macro International Inc; 1996.

9. Adewuyi A, Ogunjuyigbe P. The role of men in family planning: an examination of men's knowledge and attitude to contraceptive use among the Yorubas. African Population Studies. 2003; 18(1): 35-49.

10. Isiugu-Abanihe UC. Reproductive motivation and family size preferences among Nigerian men. Studies in Family Planning. 1994; 25(3): 149-61.

11. Bangladesh Demographic and Health Survey. Bangladesh demographic and health survey 1999-2000. National Institute of Population Research and Training (NIPORT). USA: Bangladesh, Mitra and Associates, Bangladesh and Macro International; 2001.

12. National Institute of Population Studies (NIPS) and Macro International Inc. Pakistan Demographic and Health Survey 2006-2007. Islamabad: National Institute of Population Studies (NIPS) and Macro International Inc; 2008.

13. Anonymous. New survey findings: the reproductive revolution continues. Population Reports Series M. 2003; 17: 1-42 [cited 2011 April 20]. Available from: http://www.populationreports.org/m17/.

14. Badan Kependudukan dan Keluarga Berencana Nasional. Peningkatan partisipasi pria dalam keluarga berencana dan kesehatan reproduksi di Indonesia. Cukilan Data Program KB Nasional. Jakarta: Badan Kependudukan dan Keluarga Berencana Nasional; 2003.

15. Pusat Pelatihan Pegawai dan Tenaga Program Badan Koordinasi Keluarga Berencana Nasional. Peningkatan partisipasi pria dalam KB \& KR. Jakarta: Badan Kependudukan dan Keluarga Berencana Nasional; 2005.

16. Olenick I. Women exposure to mass media is linked to attitudes toward contraception in Pakistan, India, and Bangladesh. International Family Planning Perspectives. 2000; 26 (1): 48-50.

17. Mosiur R, Rafiqul I, Matin A. Male contraceptive behavior in Rajshahi District of Bangladesh. The International Medical Journal. 2008 ; 7 (2): 15-20.

18. Abraham W, Adamu A, Deresse D. The involvement of men in family planning an application of transtheoretical model in Wolaita Soddo Town South Ethiopia. Asian Journal of Medical Sciences. 2010; 2 (2): 44-50.

19. Bhandari P, Shrestha SS. Mass media, gender, and contraception in Nepal. The Population Research Study, The Pennsylvania State University; 2005.

20. Westoff FC, Rodriguez G. The mass media and family planning in Kenya. International Family Planning Perspective. 1995; 23 (1): 26-36. 